Check for updates

Cite this: RSC Adv., 2019, 9, 22343

Received 25th June 2019

Accepted 16th July 2019

DOI: $10.1039 / \mathrm{c} 9 \mathrm{ra0} 4770 \mathrm{k}$

rsc.li/rsc-advances

\section{Phosphonic acid mediated practical dehalogenation and benzylation with benzyl halides $\dagger$}

\author{
Jing Xiao, (iD *a Yonghao $\mathrm{Ma}{ }^{a}$ Xiaofang $\mathrm{Wu}{ }^{\mathrm{a}}$ Jing Gao, ${ }^{a}$ Zilong Tang ${ }^{\mathrm{a}}$ \\ and Li-Biao Han (D) *b
}

For the first time, by using $\mathrm{H}_{3} \mathrm{PO}_{3} / \mathrm{I}_{2}$ system, various benzyl chlorides, bromides and iodides were dehalogenated successfully. In the presence of $\mathrm{H}_{3} \mathrm{PO}_{3}$, benzyl halides underwent electrophilic substitution reactions with electron-rich arenes, leading to a broad range of diarylmethanes in good yields. These transformations feature green, cheap reducing reagents and metal-free conditions. A possible mechanism was proposed.
Dehalogenation and reactions of benzylation with benzyl halides are important transformations in synthetic organic chemistry. Herein we report a simple and green method for dehalogenation and benzylation with benzyl halides under metal-free conditions. Thus, under the $\mathrm{H}_{3} \mathrm{PO}_{3} / \mathrm{I}_{2}$ system, dehalogenation took place readily with benzyl chlorides, bromides and iodides to produce the corresponding benzyl derivatives in high yields. In addition, in the absence of $\mathrm{I}_{2}$, benzyl halides underwent electrophilic substitution reactions with electronrich arenes, generating diarylmethanes efficiently.

Over the past few decades, significant efforts have been devoted to the reduction of halides. ${ }^{1}$ Among them, a variety of reducing reagents were applied to dehalogenation reactions successfully. Some of the most representative reducing agents include metal hydrides such as tri- $n$-butyltin hydrides, ${ }^{2}$ organosilanes, ${ }^{3}$ sodium borohydrides ${ }^{4}$ and lithium aluminium hydride. ${ }^{5}$ Besides, catalytic hydrogenation is also an important approach to the reduction of halides. For example, dehalogenation catalyzed by transition-metals such as nickle, ${ }^{6}$ palladium, ${ }^{3 b, 7}$ ruthenium, ${ }^{8}$ rhodium, ${ }^{9}$ indium, ${ }^{2 a, 10}$ iron $^{11}$ and cobalt ${ }^{12}$ etc. have gained increased attention. Although great progress has been achieved in dehalogenation reactions, nontoxic, green, simple and cheap reducing systems still need to be explored (Scheme 1).

Recently, our group was interested in the use of $\mathrm{H}_{3} \mathrm{PO}_{3}$ in synthetic methodologies due to its low-toxicity, ready availability

${ }^{a}$ Key Laboratory of Theoretical Organic Chemistry and Functional Molecule of Ministry of Education, School of Chemistry and Chemical Engineering, Hunan University of Science and Technology, Xiangtan 411201, China

${ }^{b}$ National Institute of Advanced Industrial Science and Technology (AIST), Tsukuba, Ibaraki 305-8565, Japan. E-mail: libiao-han@aist.go.jp; Fax: +81-29-861-6344; Tel: +81-298-61-4855

$\dagger$ Electronic supplementary information (ESI) available. See DOI: $10.1039 / \mathrm{c} 9 \mathrm{ra} 04770 \mathrm{k}$ and cheap cost. ${ }^{13}$ It is estimated that a million tons of phosphonic acid was generated as the side-product from the process of electroless nickle plating using $\mathrm{H}_{3} \mathrm{PO}_{2}$ and other chemical processes. Although most of the $\mathrm{H}_{3} \mathrm{PO}_{3}$ was lain idle as waste, we are still fascinated by the great potential ability in reduction reactions since $\mathrm{H}_{3} \mathrm{PO}_{3}$ has a reactive $\mathrm{P}(\mathrm{O}) \mathrm{H}$ bond that might serve as a green $\mathrm{H}$ source. Thus, for the first time, the $\mathrm{H}_{3} \mathrm{PO}_{3} / \mathrm{I}_{2}$ combination was used for the reduction of benzyl halides, generating a variety of benzyl derivatives in good yields. This reducing system has the advantages of being green, cheap and metal-free.

Our investigation began with the reduction of benzyl bromide in the presence of $\mathrm{H}_{3} \mathrm{PO}_{3}$ and $\mathrm{I}_{2}$. As shown in Table 1, reduction of benzyl bromide took place in benzene at $100^{\circ} \mathrm{C}$ for $22 \mathrm{~h}$, generating the desired product toluene in $48 \%$ GC yield (entry 1). Next, the temperature of the reaction was examined (entry 2 and 3). The suitable temperature was $120^{\circ} \mathrm{C}$ and gave the product in $76 \%$ yield. Further screening of the amount of $\mathrm{I}_{2}$ or $\mathrm{H}_{3} \mathrm{PO}_{3}$ failed to improve the reaction efficiency (entry 4-6). Among the solvents examined, polar solvents such as chlorobenzene, $\mathrm{CH}_{3} \mathrm{CN}$ and dioxane gave poor results (entry 7-9). To our delight, a weak polar solvent DCE (1,2dichloroethane) was a relatively good solvent with a yield of $69 \%$ (entry 10). When prolonging the reaction time to $36 \mathrm{~h}$, DCE gave a better result than benzene with a yield of $92 \%$ (entry 11 and 12). The yield of the product could not be increased by elevating the temperature to $130^{\circ} \mathrm{C}$ in DCE (entry 13).

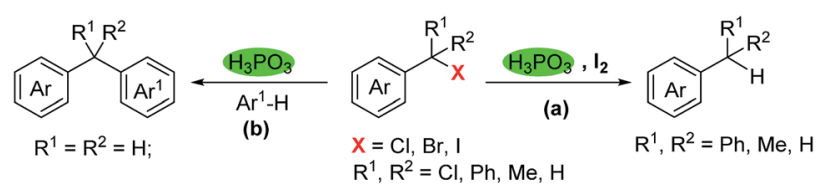

Scheme 1 Phosphonic acid mediated dehalogenation and benzylation with benzyl halides. 
Table 1 Optimization of the reaction conditions ${ }^{a}$

\begin{tabular}{|c|c|c|c|c|c|}
\hline & $1 \mathrm{a}$ & $\frac{\mathrm{H}_{3} \mathrm{PO}_{3}}{\text { solvent, tem }}$ & $\underset{22 \mathrm{~h}, \mathrm{~N}_{2}}{\stackrel{\mathrm{I}_{2}}{\longrightarrow}}$ & $\stackrel{H}{K}_{H}^{H}$ & \\
\hline Entry & $\mathrm{H}_{3} \mathrm{PO}_{3}$ (equiv.) & $\mathrm{I}_{2}$ (equiv.) & Solvent & Temp $/{ }^{\circ} \mathrm{C}$ & Yield (\%) \\
\hline 1 & 2.0 & $10 \%$ & Benzene & 100 & $48 \%$ \\
\hline 2 & 2.0 & $10 \%$ & Benzene & 120 & $76 \%$ \\
\hline 3 & 2.0 & $10 \%$ & Benzene & 130 & $75 \%$ \\
\hline 4 & 2.0 & $15 \%$ & Benzene & 120 & $74 \%$ \\
\hline 5 & 2.0 & $5 \%$ & Benzene & 120 & $70 \%$ \\
\hline 6 & 3.0 & $10 \%$ & Benzene & 120 & $64 \%$ \\
\hline 7 & 2.0 & $10 \%$ & PhCI & 120 & $21 \%$ \\
\hline 8 & 2.0 & $10 \%$ & $\mathrm{CH}_{3} \mathrm{CN}$ & 120 & $7 \%$ \\
\hline 9 & 2.0 & $10 \%$ & Dioxane & 120 & $26 \%$ \\
\hline 10 & 2.0 & $10 \%$ & DCE & 120 & $69 \%$ \\
\hline 11 & 2.0 & $10 \%$ & DCE & 120 & $92 \%{ }^{b}$ \\
\hline 12 & 2.0 & $10 \%$ & Benzene & 120 & $61 \%^{b}$ \\
\hline 13 & 2.0 & $10 \%$ & DCE & 130 & $82 \%$ \\
\hline
\end{tabular}

${ }^{a}$ Conditions: a mixture of $\mathbf{1 a}(0.3 \mathrm{mmol}), \mathrm{H}_{3} \mathrm{PO}_{3}$, and $\mathrm{I}_{2}$ in solvent (0.6 $\mathrm{mL}$ ) was stirred at indicated temperature for the $22 \mathrm{~h}$. Yield based on GC yield using dodecane as an internal standard. ${ }^{b} 36 \mathrm{~h}$.

With the optimized reaction conditions in hand, the scope of the reaction with respect to benzyl halides was examined (Table 2). Benzyl bromide was reduced to the corresponding product in $84 \%$ GC yield, albeit $38 \%$ isolated yield was obtained due to its low boiling point (2a). Bromides bearing methyl or phenyl groups at the para-position on benzene were reduced smoothly to afford the product in high yields ( $2 \mathbf{b}$ and $2 \mathbf{c}$ ). Interestingly, substrates containing halogens such as $\mathrm{F}, \mathrm{Cl}$ and $\mathrm{Br}$ at the paraposition on benzene stayed intact during the dehalogenation

Table 2 Reduction of the benzyl bromide derivatives with $\mathrm{H}_{3} \mathrm{PO}_{3} / \mathrm{I}_{2}{ }^{a}$

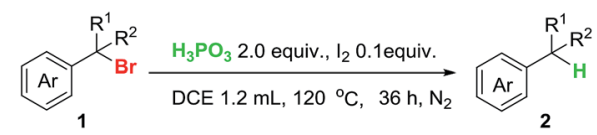

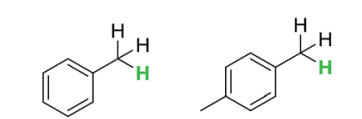

2a: $38 \%(84 \%)$<smiles>Cc1ccc(Cl)cc1</smiles>

2b: $41 \%(92 \%)$<smiles>C=Cc1ccc(Br)cc1</smiles>

2e: $49 \%(98 \%) \quad$ 2f: $68 \%(97 \%)$<smiles>O=[N+]c1ccc(C=[W])cc1</smiles><smiles>CC(c1ccccc1)c1ccccc1</smiles>

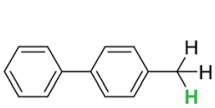

2c: $98 \%$<smiles>C=Cc1ccc(C(F)(F)F)cc1</smiles>

$2 \mathrm{~g}: 26 \%(72 \%)$

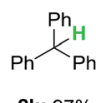

2k: $97 \%$

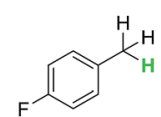

2d: $32 \%(89 \%)$
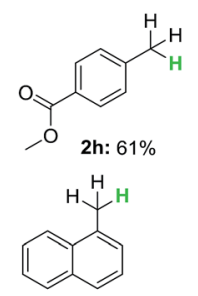

21: $78 \%$
${ }^{a}$ Conditions: a mixture of $1(0.6 \mathrm{mmol}), \mathrm{H}_{3} \mathrm{PO}_{3}$, and $\mathrm{I}_{2}$ in DCE was stirred at $120{ }^{\circ} \mathrm{C}$ for $36 \mathrm{~h}$. Isolated yield based on three parallel reactions. Yield in parenthesis are GC yield. (2d-2f). Other electron-deficient bromides having $\mathrm{CF}_{3}, \mathrm{C}(\mathrm{O})$ $\mathrm{OMe}$ and $\mathrm{NO}_{2}$ groups were also tolerated well in this reductive system $(\mathbf{2 g}-\mathbf{- 2 i})$. Secondary and tertiary benzyl bromides such as (1-bromoethyl)benzene and (bromomethanetriyl)tribenzene also underwent this reduction successfully generating the product in $95 \%$ and $97 \%$ yield, respectively ( $2 \mathbf{j}$ and $\mathbf{2 k}$ ). When 1(bromomethyl)naphthalene was subjected into the reaction, $78 \%$ yield of the product was obtained (2l). Unfortunately, alkyl and aryl bromides did not go through this dehalogenation reaction.

We next extended the scope of benzyl halides under similar conditions. As shown in Table 3, benzyl chloride also proceeded smoothly (2a), and various reduction products were obtained. Chlorides bearing substituents ( $\mathrm{Me}, \mathrm{F}, \mathrm{Cl}$ and $\mathrm{Br}$ ) were suitable for this reduction reaction, generating the corresponding product in good yields $(\mathbf{2 b}, \mathbf{2 d - 2 f})$. With regard to electronwithdrawing group under $\mathrm{H}_{3} \mathrm{PO}_{3} / \mathrm{I}_{2}$ system, we observed that $\mathrm{CF}_{3}, \mathrm{CN}$ and $\mathrm{NO}_{2}$ substituents were tolerated in good yields $(2 \mathrm{~g}$, $2 \mathbf{m}$ and $2 \mathbf{i}$ ). Furthermore, secondary chlorides such as (1chloroethyl)benzene and chlorodiphenylmethane were also worked well in this transformation, providing the product in high yields (2j and $2 \mathbf{n}$ ). Gratefully, large steric hindrance triphenylmethane chloride was reduced readily under the present condition in $97 \%$ yield (2k). Finally, we conducted the dehalogenation of benzotrichloride and benzyl iodide to explore possible reduction of polyhalogenated substrates and iodides. Indeed, 2a was formed in $41 \%$ and $88 \%$ yield, respectively.

During the above studies of dehalogenation of benzyl halides, we found that interestingly, when the reaction was performed in the absence of $I_{2}$, electrophilic substituent

Table 3 Reduction of the benzyl chloride derivatives with $\mathrm{H}_{3} \mathrm{PO}_{3} / \mathrm{I}_{2}{ }^{a}$

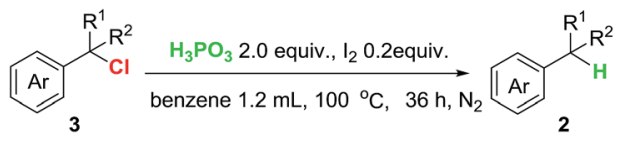

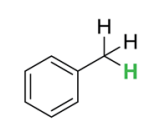

2a: $25 \%(80 \%)$<smiles>C=Cc1ccc(Br)cc1</smiles>

2f: $65 \%(84 \%)^{b}$

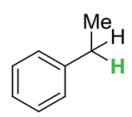

2j: $41 \%(98 \%)^{2}$

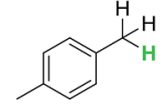

2b: $34 \%(71 \%)$<smiles>C=Cc1ccc(F)cc1</smiles>

2d: $22 \%(65 \%)$

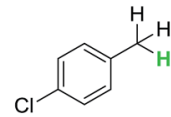

2e: $37 \%(73 \%)$<smiles>C=Cc1ccc(C#N)cc1</smiles>

$2 \mathrm{~m}: 53 \%^{d}$<smiles></smiles>

2i: $42 \%$

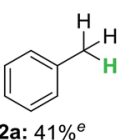

$25 \%(88 \%)^{f}$
${ }^{a}$ Conditions: a mixture of $3(0.6 \mathrm{mmol}), \mathrm{H}_{3} \mathrm{PO}_{3}$, and $\mathrm{I}_{2}$ in benzene was stirred at $100^{\circ} \mathrm{C}$ for $36 \mathrm{~h}$. Isolated yield based on three parallel reactions. Yield in parenthesis are GC yield. ${ }^{b} 120{ }^{\circ} \mathrm{C} .{ }^{c} 4.0$ equiv. $\mathrm{H}_{3} \mathrm{PO}_{3} .{ }^{d} 130{ }^{\circ} \mathrm{C}$. ${ }^{e}$ Benzotrichloride and 5.0 equiv. $\mathrm{H}_{3} \mathrm{PO}_{3}$ was used. ${ }^{f}$ Benzyl iodide was used. 
reaction took place to affording diarylmethane in excellent yields. Diarylmethane are widely used in organic synthesis, pharmaceutical development and material science. ${ }^{14}$ Among the methods reported, Friedel-Crafts (FC) benzylation of arenes ${ }^{15}$ and transition-metal catalysed cross coupling reaction ${ }^{16}$ are the important approaches to preparing these compounds. However, those methods are usually need equivalent expensive Lewis acids, metal and not readily available materials. Although various strategies for the metal-free access to diarylmethanes have been explored, ${ }^{17}$ a more simple, practical, and greener method for their preparation are highly desirable.

As shown in Table 4, various arenes were subjected into this electrophilic substitution reaction. Thus, in the presence of $\mathrm{H}_{3} \mathrm{PO}_{3}$, benzyl chlorides and bromides underwent this transformation successfully with benzene or mesitylene to afford the corresponding diarylmethanes in good to excellent yields ( $\mathbf{2 n}$ and $\mathbf{4 a}$ ). Gratifying, electron-rich arenes such as toluene, phenol and anisole were also compatible in this reaction conditions with isomer products generated (4b-4d). In addition, when chlorobenzene was used as the substrate, good yield of the corresponding product was observed (4e). Subsequently, a serious of benzyl halides with benzene were investigated in the presence of $\mathrm{H}_{3} \mathrm{PO}_{3}$. Benzyl halides bearing methyl, phenyl, fluoride, chloride and bromide led to good to high yield of the products $(\mathbf{4 b}, \mathbf{4 f}-\mathbf{4 h})$.

Table 4 Benzylation of arenes with benzyl halides ${ }^{a}$

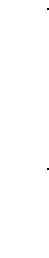$$
\text { Ar } \frac{\mathrm{H}_{3} \mathrm{PO}_{3} 2.0 \text { equiv. }}{\mathrm{Ar}-\mathrm{H}(1.2 \mathrm{~mL}), 130{ }^{\circ} \mathrm{C}, 24 \mathrm{~h}, \mathrm{~N}_{2}} \mathrm{Ar}
$$$$
1 \text { or } 3
$$$$
4
$$

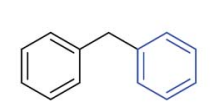

2n: $\mathrm{X}=\mathrm{Cl} ; 84 \%$; $\mathrm{X}=\mathrm{Br} ; 87 \%^{\mathrm{b}}$

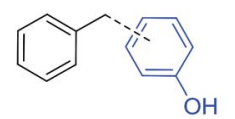

$\mathrm{OH}$

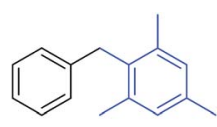

4a: $\begin{aligned} \mathrm{X}=\mathrm{Cl} ; 95 \% ; \\ \mathrm{X}=\mathrm{Br} ; 96 \% \mathrm{~b}\end{aligned}$

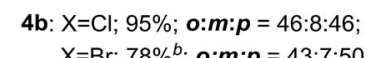
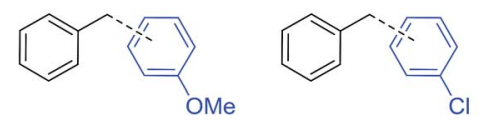

4c: $\mathrm{X}=\mathrm{Cl} 99 \% ; \boldsymbol{o : p}=64: 36$ 4d: $\mathrm{X}=\mathrm{Cl} ; 94 \% ; \boldsymbol{o : p}=49: 51 \quad \mathbf{4 e}: \mathrm{X}=\mathrm{Cl} ; 72 \%^{c}$

$\mathrm{X}=\mathrm{Br} 98 \%^{b} ; \boldsymbol{o : p}=55: 45 \quad \mathrm{X}=\mathrm{Br} ; 92 \%^{b} ; \boldsymbol{o}: \boldsymbol{p}=43: 57 \quad \boldsymbol{o}: \boldsymbol{m}: \boldsymbol{p}=47: 2: 51$
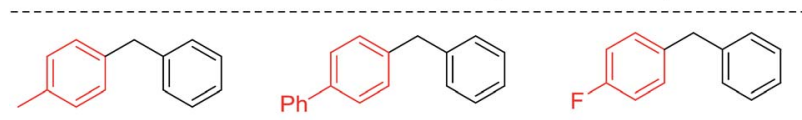

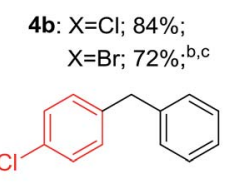

4e: $\mathrm{X}=\mathrm{Cl} ; 92 \%{ }^{b, c}$ $\mathrm{X}=\mathrm{Br} ; 56 \%^{b, c}$

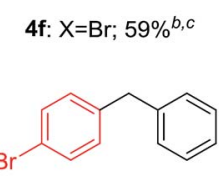

4h: $\mathrm{X}=\mathrm{Cl} ; 81 \%{ }^{b, c}$ $\mathrm{X}=\mathrm{Br} ; 53 \%^{\mathrm{b}, \mathrm{c}}$

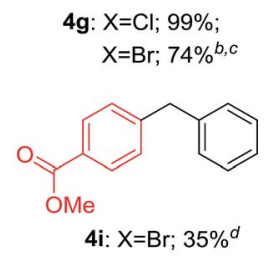

4i: $\mathrm{X}=\mathrm{Br} ; 35 \%^{\mathrm{d}}$
${ }^{a}$ Conditions: a mixture of 1 or $3(0.6 \mathrm{mmol})$ and $\mathrm{H}_{3} \mathrm{PO}_{3}$ in arenes was stirred at $130{ }^{\circ} \mathrm{C}$ for $24 \mathrm{~h}$. Isolated yield based on three parallel reactions. Isomer ratio was determined by GC. ${ }^{b} 36 \mathrm{~h} .^{c} 150{ }^{\circ} \mathrm{C} .{ }^{d} 160{ }^{\circ} \mathrm{C}$.
It is worth noting that benzyl bromide with electron-drawing group such as methyl ester was also applicable in this reaction, albeit in moderate yield of the product (4i). Unfortunately, the reaction gave trace product with benzyl halides having strong electron-withdrawing groups such as nitro or trifluoromethyl group.

To highlight the synthetic utility of these transformation, some gram-scale reactions were conducted. As shown in Scheme 2, $12 \mathrm{mmol}$ (chloromethylene)dibenzene $3 \mathbf{n}$ was reduced smoothly in the presence of 2.0 equiv. $\mathrm{H}_{3} \mathrm{PO}_{3}$ and $10 \mathrm{~mol} \% \mathrm{I}_{2}$ in benzene at $130{ }^{\circ} \mathrm{C}$ for $36 \mathrm{~h}$, generating $1.956 \mathrm{~g}$ product in $97 \%$ isolated yield (eqn (1)). Besides, we were pleased to find that the gram scale synthesis of diphenylmethane by reaction of benzyl chloride with benzene was also achieved (eqn (2)). The above results revealed that these reactions were practical and have the potential to scale up.

Finally, some control experiments were conducted to evaluate the different halides and electron effect of these reactions. 4-Methylbenzyl chloride and 4-methylbenzyl bromide were reduced to the product with $20 \%$ and $31 \%$ substrate conversion, respectively (eqn (3)). Benzyl bromides bearing electron-donating group methyl, $\mathrm{H}$ and electron-withdrawing group $\mathrm{CF}_{3}$ were also subjected into the reaction in one pot, and the corresponding product were obtained in $17 \%, 9 \%$ and trace yield with a large amount of substrate recovered, respectively (eqn (4)). Similarly, the benzylation of benzene by the above three bromides affording the corresponding diarylmethanes in a downward trend in yields (eqn (5)). The above results revealed that benzyl bromides were more reactive than benzyl chloride in dehalogenation reactions. Besides, in the same type of halides, electron-donating group having more positive influence than electron-deficient whether in reduction or benzylation reactions, which may suggest that these reactions were involving a carbon cation mechanism (Scheme 3).

Based on the above results and previous reports, ${ }^{13}$ a possible mechanism was proposed in Scheme 4 . HI was generated in situ by reaction of $\mathrm{H}_{3} \mathrm{PO}_{3}$ and $\mathrm{I}_{2}$, halogen exchange between benzyl halides and $\mathrm{HI}$ afforded intermediate $\mathbf{A}$, further reduction of $\mathbf{A}$ by HI to give the corresponding product (eqn (a)). For benzylation of arenes by halides, we deduced that carbon cation intermediate $\mathbf{B}$ was generated via $\mathrm{C}-\mathrm{X}$ bond cleavage in the presence of $\mathrm{H}_{3} \mathrm{PO}_{3}$, B underwent electrophilic substitution reaction with arenes to afford the corresponding diarylmethanes (eqn (b)).

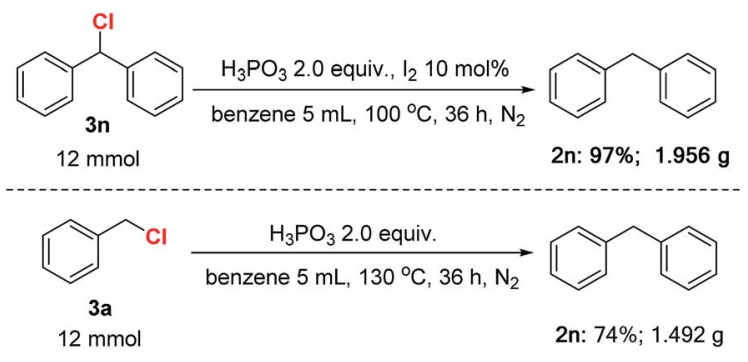

Scheme 2 Gram-scale reactions. 


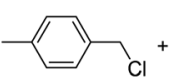

$+$

3b: $0.15 \mathrm{mmol}$

$20 \%$ conversion $31 \%$ conversion
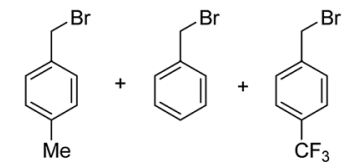

1b: $0.1 \mathrm{mmol}$ 1a: $0.1 \mathrm{mmol} 1 \mathrm{~g}: 0.1 \mathrm{mmol}$

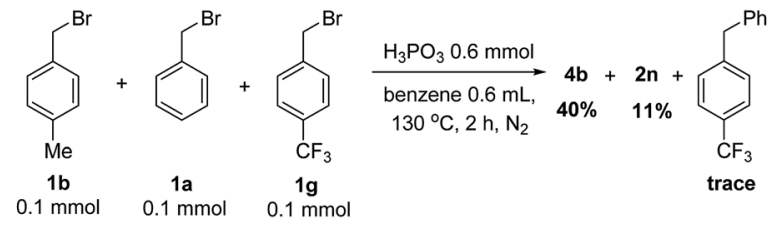

Scheme 3 Control experiments.

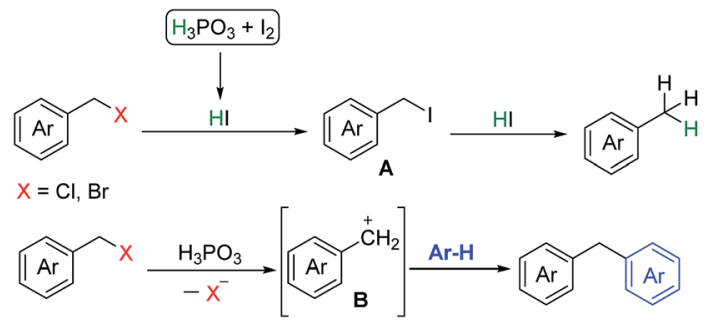

(a)

Scheme 4 Possible mechanism.

\section{Conclusions}

In summary, we report a practical method for dehalogenation of benzyl halides and preparation of diarylmethanes by using a $\mathrm{H}_{3} \mathrm{PO}_{3}$ system. Various benzyl halides could be readily reduced by the $\mathrm{H}_{3} \mathrm{PO}_{3} / \mathrm{I}_{2}$ combination for the first time. In the absence of $\mathrm{I}_{2}$, electrophilic substitution reactions between benzyl halides and arenes occurred smoothly, furnishing diarylmethanes in good yields. This method provides a simple, cheap and green approach for the reduction of benzyl halides and synthesis of diarylmethanes.

\section{Conflicts of interest}

There are no conflicts to declare.

\section{Acknowledgements}

JX is thankful for a postdoc fellowship from AIST and financial support from the National Natural Science Foundation of China (21703061) and the Natural Science Foundation of Hunan province (2017JJ3081).

\section{Notes and references}

1 (a) F. Alonso, I. P. Beletskaya and M. Yus, Chem. Rev., 2002, 102, 4009-4092; (b) G. Chelucci, S. Baldino, G. A. Pinna and G. Pinna, Curr. Org. Chem., 2012, 16, 2921-2945; (c) C. E. Castro, Reviews of Environmental Contamination and Toxicology, Springer, New York, 1998, 155, pp. 1-67; (d) G. L. Larson, Org. React., 2008, 71, 5-119; (e) T. Hennebel, J. Benner, P. Clauwaert, L. Vanhaecke, P. Aelterman, R. Callebaut, N. Boon and W. Verstraete, Biotechnol. Lett., 2011, 33, 89-95; $(f)$ Á. F. Cañete, C. O. Salas and F. C. Zacconi, Molecules, 2013, 18, 398-407.

2 (a) K. Inoue, A. Sawada, I. Shibata and A. Baba, Tetrahedron Lett., 2001, 42, 4661-4663; (b) A. Rahm, R. Amardeil and M. Degueil-Castaing, J. Organomet. Chem., 1989, 371, 4-8; (c) M. Pereyre, J. P. Quintard and A. Rahm, Reduction of Organic Halides in Tin in Organic Synthesis, Butterworth, London, 1986.

3 (a) C. Chatgilialoglu, Acc. Chem. Res., 1992, 25, 188-194; (b) R. Boukherroub, C. Chatgilialoglu and G. Manuel, Organometallics, 1996, 15, 1508-1510; (c) J. Yang and M. Brookhart, Adv. Synth. Catal., 2009, 351, 175-187.

4 S. Krishnamurthy and H. C. Brown, J. Org. Chem., 1980, 45, 849-856.

5 S. Krishnamurthy and H. C. Brown, J. Org. Chem., 1982, 47, 276-280.

6 (a) A. F. Barrero, E. J. Alvarez-Manzaneda, R. Chahboun, R. Meneses and J. L. Romera, Synlett, 2001, 4, 485-488; (b) S. Zinovyev, A. Perosa, S. Yufit and P. Tundo, J. Catal., 2002, 211, 347-354; (c) J. M Khurana, S. Kumar and B. Nand, Can. J. Chem., 2008, 86, 1052-1054.

7 (a) T. Hara, K. Mori, M. Oshiba, T. Mizugaki, K. Ebitania and K. Kaneda, Green Chem., 2004, 6, 507-509; (b) G. L. Larson and J. L. Fry, Org. React., 2008, 71, 1-737; (c) T. Hara, T. Kaneta, K. Mori, T. Mitsudome, T. Mizugaki, K. Ebitanic and K. Kaneda, Green Chem., 2007, 9, 1246-1251.

8 (a) A. Jana, J. Mondal, P. Borah, S. Mondal, A. Bhaumik and Y. Zhao, Chem. Commun., 2015, 51, 10746-10749; (b) M. C. Haibach, B. M. Stoltz and R. H. Grubbs, Angew. Chem., Int. Ed., 2017, 56, 15123-15126.

9 K. Fujita, M. Owaki and R. Yamaguchi, Chem. Commun., 2002, 2964-2965.

10 Á. F. Cañete, C. O. Salas and F. C. Zacconi, Molecules, 2013, 18, 398-407.

11 H. Guo, K.-i. Kanno and T. Takahashi, Chem. Lett., 2004, 33, 1356-1357.

12 (a) B. Sahoo, A. E. Surkus, M. M. Pohl, J. Radnik, M. Schneider, S. Bachmann, M. Scalone, K. Junge and M. Beller, Angew. Chem., Int. Ed., 2017, 56, 11242-11247; (b) F. Ungváry and L. Markó, J. Organomet. Chem., 1980, 193, 379-382.

13 J. Xiao and L.-B. Han, Tetrahedron, 2019, 75, 3510-3515.

14 (a) J. S. Kim and D. T. Quang, Chem. Rev., 2007, 107, 37803799; (b) Y.-Q. Long, X.-H. Jiang, R. Dayam, T. Sanchez, R. Shoemaker, S. Sei and N. Neamati, J. Med. Chem., 2004, 47, 2561-2573; (c) W. N. Washburn, J. Med. Chem., 2009, 52, 1785-1794; (d) T. Brotin and J.-P. Dutasta, Chem. Rev., 2009, 109, 88-130.

15 (a) C. Friedel and J. M. Crafts, Compt. Rend., 1877, 84, 1450; (b) G. A. Olah, S. J. Kuhn and S. H. Flood, J. Am. Chem. Soc., 
1962, 84, 1688-1695; (c) M. Rueping and B. J. Nachtsheim, Beilstein J. Org. Chem., 2010, 6, 6, DOI: 10.3762/bjoc.6.6.

16 (a) H. Jiang, S.-C. Sha, S. A. Jeong, B. C. Manor and P. J. Walsh, Org. Lett., 2019, 21, 1735-1739; (b) J. Xiao, T. Chen and L.-B. Han, Org. Lett., 2015, 17, 812-815; (c) J. Xiao, a. J. Yang, T. Chen and L.-B. Han, Adv. Synth. Catal., 2016, 358, 816-819; (d) B. Liégault, J. L. Renaud and C. Bruneau, Chem. Soc. Rev., 2008, 37, 290-299.
17 (a) R.-J. Tang, T. Milcent and B. Crousse, J. Org. Chem., 2018, 83, 14001-14009; (b) G. Schafer and J. W. Bode, Angew. Chem., Int. Ed., 2011, 50, 10913-10916; (c) J. Zhu, M. Perez and D. W. Stephan, Angew. Chem., Int. Ed., 2016, 55, 84488451; (d) P. A. Champagne, Y. Benhassine, J. Desroches and J. F. Paquin, Angew. Chem., Int. Ed., 2014, 53, 1383513839. 